Dept. of Food Control

Faculty of Veterinary Medicine, Zagazig University, Egypt.

\title{
OCCURRENCE OF LISTERIA AND YERSINIA SPECIES IN MILK AND SOME MILK PRODUCTS
}

(With 4 Tables)

\author{
By \\ S.F.A. ABD EL AAL AND M.A-H.B. ATTA \\ (Received at 20/8/2009)
}

مدي تواجد ميكروبات الليستيريا واليرسينيا في اللبن وبعض منتجاته

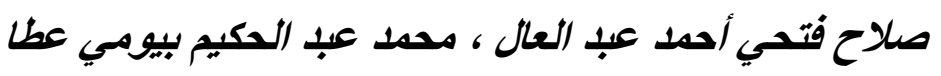

أجريت هذه الدراسة علي 200 عينة من اللبن الخام وبعص منتجاته وتشتمل علي 100 عن عينة

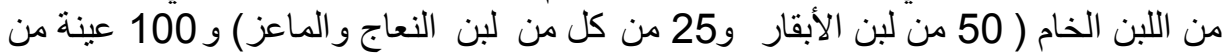

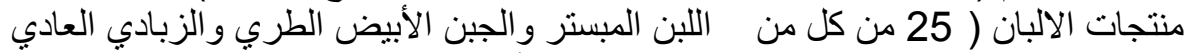

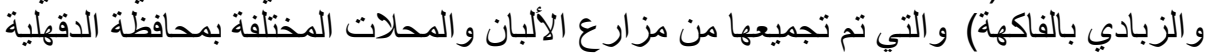

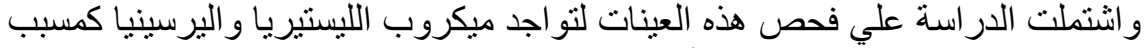

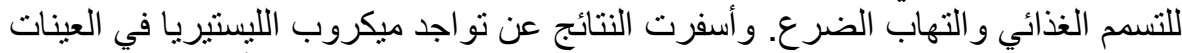

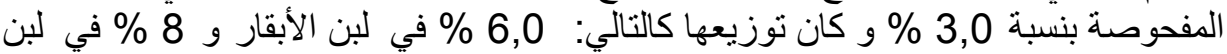

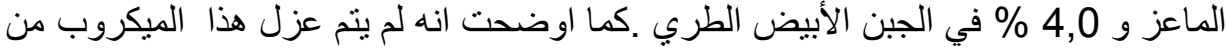

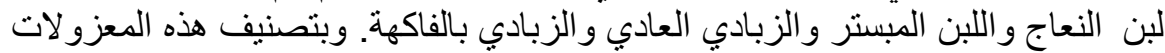

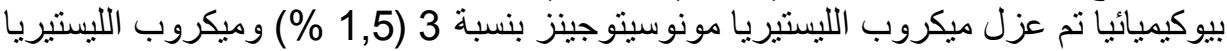
اونوكو ا بنسبة 5 (2,5 \%) وميكروب الليستيريا ولثيميري بنسبة 2 (1,0 \% \% \%). كما تم عزل

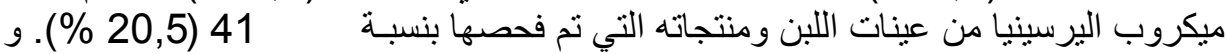

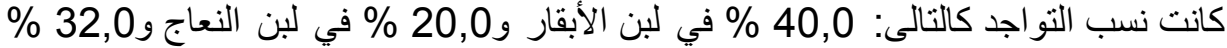

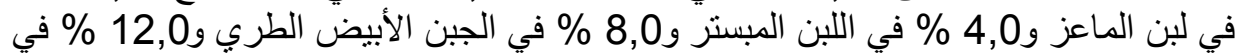

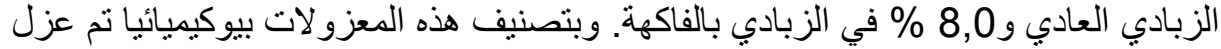

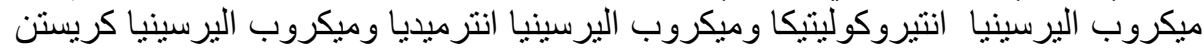

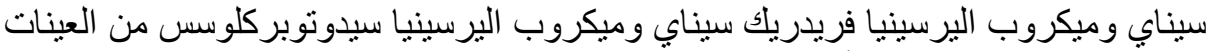

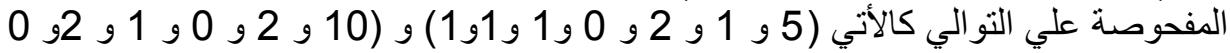

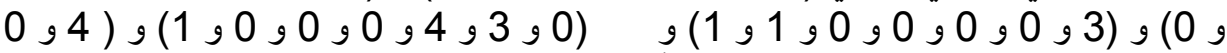

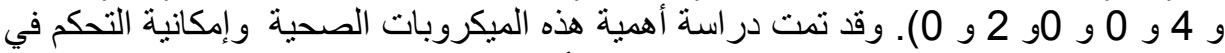

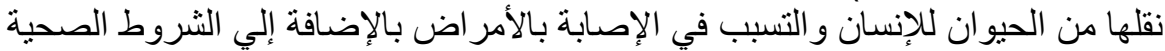
الو اجب تو افرها لإنتاج منتج صحي عالي الجودة الإنة خالالي من الأمر اض.

\section{SUMMARY}


Two hundred raw milk and dairy product samples (50 cow's milk and 25 each of sheep's milk, goat's milk, pasteurized milk, white soft cheese, plain yoghurt and fruit yoghurt) were collected from dairy farms and different localities, markets and shops in El Dakahlia Province, Egypt and examined for the presence of Listeria and Yersinia species as food poisoning and mastitis causing organisms. The incidence of Listeria spp. in raw milk and dairy product samples was $3.0 \%$ and their distributions were $6.0 \%$ in cow's milk, $8.0 \%$ in goat's milk, $4.0 \%$ in white soft cheese samples and can't be detected in sheep's milk, pasteurized milk and both fruit and plain yoghurt samples. The incidence of Listeria monocytogens in raw milk and dairy product samples was $3(1.5 \%)$, the other Listeria spp. were L. innocua 5 (2.5\%) and L. welshimeri 2 (1.0\%). Yersinia spp. could be isolated from $41(20.5 \%)$ of examined raw milk and dairy product samples. The incidence percentages were $40.0 \%$ in cow's milk, $20.0 \%$ in sheep's milk, $32.0 \%$ in goat's milk, $4.0 \%$ in pasteurized milk, $8.0 \%$ in white soft cheese, $12.0 \%$ in fruit yoghurt and $8.0 \%$ in plain yoghurt. Yersinia enterocolitica, Yersinia intermedia, Yersinia kristensenii, Yersinia frederiksenii and Yersinia pseudotuberculosis could be detected in $(5,1,2,0,1,1$ and 1$)$; $(10,2,0,1,2,0$ and 0$)$; $(3,0,0,0,0,1$ and 1$) ;(0,3,4,0,0,0$ and 1$)$ and (4, 0, 4, 0, 0, 2 and 0$)$ of examined samples, respectively. The sanitary and public health importance of these organisms as well as control measures to improve the quality of dairy products and to safeguard the consumers from infection were discussed.

Key words: Listeria, yersinia milk, dairy products.

\section{INTRODUCTION}

Listeria is a ubiquitous gram-positive microaerophilic bacterium comprises seven species: Listeria monocytogenes, Listeria innocua, Listeria ivanovii, Listeria welshimeri, Listeria seeligeri, Listeria grayi and Listeria murrayi. Among them, L. monocytogenes which is a major pathogenic microorganism capable of causing severe Listeriosis infections in humans (encephalitis, meningitis and septicaemia especially in immunocompromised individuals) and in animals (mastitis, diarrhea and gastroenteritis) (Herman et al., 1995; Vela et al., 2001; Siegman-Igra et al., 2002; McLauchlin et al., 2004; Aygun and Pehlivanlar, 2006). and L. ivanovii which is rarely pathogenic for humans (McLauchlin, 1997 b; Swaminathan, 2001). 
Listeriosis was discovered more than 70 years ago at the end of world war (McLauchlin, 1997 a). Since then, Listeriosis has emerged as an atypical foodborne illness of major public health concern because the severity of the disease, the high rate (20-30\% in some epidemic cases), the long incubation period and the predilection for individuals who have an underlying condition which leads to impairment of T-cell-mediated immunity (Franz, 2003). Listeriosis characterized by systemic illness such as premature birth, miscarriage, infection of newborn, stillbirth, septicaemia, meningitis, central nervous system infection, endocarditis, encephalitis and death. A person with listeriosis has fever, muscle aches and sometimes gastrointestinal symptoms such as nausea or diarrhoea. If the infection spreads to nervous system, symptoms such as headache, stiff neck, confusion, loss of balance or convulsions can occur. Risk groups are pregnant women, newborns, the elderly, persons with weak immune systems as AIDS, cancer, diabetes are also risk groups and sometimes healthy people.

Listeria monocytogens has been reported to cause mastitis and can be shed in milk and feces. Shedding in milk can occur from both clinically affected and a symptomatic animals, thus constituting a potential public health hazard. Antimicrobials used as growth promoters in animal feed have reduced the impact of infectious diseases (diarrhea, skin and organ abscesses and mastitis) but led to the dissemination of antimicrobial-resistant L. monocytogenes into the environment (Teuber, 1999; Jansen et al., 2003).

The importance of dairy-based food as a vehicle for the transmission of various diseases has been documented; especially in countries where hygienic standards are not strictly enforced (MeyerBroseta et al., 2003). L. monocytogenes has been involved in many outbreaks and sporadic cases of disease primarily associated with the consumption of pasteurized milk, cheeses made from unpasteurized milk and other dairy based products that serve as good medium for the growth and survival of many pathogenic organisms in both industrialized and developing countries (Makino et al., 2005; Manfreda et al., 2005). The organism has been consistently can multiply in raw milk at a wide range of temperatures, including refrigeration. Also, it is more heat tolerant than many other pathogens, although current pasteurisation methods are considered to be effective. Post pasteurisation contamination with Listeria monocytogens can be occurred. The outbreaks most often occurred from consumption of raw milk and dairy products because the Listeria organism capable of slow multiplication in refrigerated foods 
(Fleming et al., 1985). Important characteristics of L. monocytogenes are its ability to grow at temperatures of $1-44^{\circ} \mathrm{C}$, at $\mathrm{pH}$ values of 5.0 and above, in high salt concentrations, and are relative resistance to freezing and drying (Lovett, 1989). Attention has therefore been directed to listeriosis, both as a clinical entity of increasing importance and as a substantial problem for the food industry.

Yersinia enterocolitica is an ubiquitous facultative anaerobic, Gram-negative, non spore forming, short rod shaped bacterium potentially pathogenic for man and has been recognized as a cause of acute gastroenteritis and mesenteric adentitis, and a variety of extraintestinal disorders like erythema nodosum or polyarthritis in humans (Robins-Browne, 1997). Human yersiniosis in Europe involves only few isolates of bio/serogroup 1B/O: 8, 2/O: 5, 27, 2/O: 9 and 4/O: 3 (Bottone, 1997). Although pigs are regarded as major reservoirs of pathogenic Yersinia enterocolitica, this microorganism has been isolated in different countries particularly from raw milk and pasteurised milk which are being implicated in several outbreaks of yersiniosis but the occurrence in derived dairy products was rarely reported (Schiemann, 1978; Larkin et al., 1991). Food has been proposed to be the main source of intestinal yersiniosis, although pathogenic isolates have seldom been recovered from food samples. The psychrotrophic nature of this organism is a particular significance in milk and milk products that are normally stored at low temperatures. In raw milk Yersinia enterocolitica strains were able to survive in the presence of high numbers of competing microorganisms and were able to maintain the virulence plasmid during extended storage at refrigeration temperature (Larkin et al., 1991). This study was performed to reveal out the prevalence of Listeria and Yersinia spp. in different types of milk and some dairy products purchased at the retail level in El-Dakahlia Province, Egypt, and to shed the light on the prevention of human Listeriosis and Yersiniosis.

\section{MATERIALS and METHODS}

\section{1- Collection of samples (A.P.H.A., 1992):}

a- Raw milk: One hundred raw milk samples (50 cow's milk, 25 each of sheep's and goat's milk) were collected from the dairy farms in El Dakahlia Province, Egypt. Each sample (about $50 \mathrm{~mL}$ ) was collected in a clean, dry and sterile sampling bottle then labeled to identify the source, site and date of sampling. 
b- Dairy products: One hundred random samples of dairy products (25 each of pasteurized milk, white soft cheese, plain yoghurt and fruit yoghurt) were collected in their retail packs from different localities, markets and shops in El Dakahlia Province, Egypt. All collected samples were placed in an insulated sampling case containing ice to ensure a storage temperature $<5^{\circ} \mathrm{C}$ and transported to the laboratory without delay for microbiological examination.

\section{2- Isolation and identification of Listeria species (Yoshida et al., 1998):}

a- Enrichment: $3 \mathrm{~mL}$. or gm. of milk and dairy products were enriched by adding $30 \mathrm{~mL}$. of Listeria Enrichment Broth Modified (Difco) and incubating at $30^{\circ} \mathrm{C}$ for $48 \mathrm{hrs}$.

b- Platting: $0.1 \mathrm{~mL}$. of each enriched culture was streaked on PALCAM agar plate (Merck) supplemented with Listeria selective supplement (Merck) according to Van-Netten et al. (1989) which was incubated at $37^{\circ} \mathrm{C}$ for 24 to $48 \mathrm{hr}$. Typical Listeria-like colonies having developed on PALCAM agar plates (grey-green, $2 \mathrm{~mm}$. in diameter and have black, sunken centers were selected. Suspicious colonies were subcultured on Tryptone-Soya Agar (Nissui) supplemented with $0.5 \%$ yeast extract (Oxoid) for characterization and purification. The plates were incubated at $37^{\circ} \mathrm{C}$ for $24 \mathrm{hr}$.

c- Identification: Colonies are bluish grey by normal illumination. Listerial isolates were biochemically identified by using API-Listeria test (Bio Merieux, La Balme-Les-Grottes, France) which was specifically designed for the genus listeria and include 10 biochemical differentiation tests in a microtube format (Bille et al., 1992).

3- Isolation and identification of Yersinia species (Landgraf, 1993):

a- Enrichment: $25 \mathrm{~mL}$. or gm. of milk and dairy products were homogenized with $225 \mathrm{~mL}$. of SB broth (phosphate-buffered saline, sorbitol $1 \%$ and bile salts $0.15 \%$ ) and incubated at $4^{\circ} \mathrm{C}$ for up to 21 days (Aulisio and Stanfield, 1984).

b- Platting: The selective enrichment medium $(0.1 \mathrm{~mL}$. of each culture) was plated on Cefsulodin-Irgasan-Novobiocin (CIN) agar plate (Merck) supplemented with Yersinia selective supplement (Merck). The plates were incubated at $30^{\circ} \mathrm{C}$ for 24 to $48 \mathrm{hrs}$. After $24 \mathrm{hr}$. of incubation the typical colonies of Yersinia appear as bulls eye colonies $(1.5 \mathrm{~mm}$. in diameter, deep red or purple center with sharp edge and surrounded by translucent border (Hamama et al., 1992). The plates were read again after $48 \mathrm{hr}$. and presumptive colonies were removed for further testing. 
c- Identification: Colonies were inoculated onto Nutrient Agar for purification then all isolates were identified by using the API-20E (Bio Merieux, Nürtingen, Germany) system which still accepted as the gold standard for the rapid identification of Yersinia enterocolitica (Neubauer et al., 1998). The API-20E strips were inoculated following the manufacturer's instructions. The API-20E system was incubated for $18-20 \mathrm{hr}$. at $25^{\circ} \mathrm{C}$ (Bercovier et al., 1980).

\section{RESULTS}

Table 1: Incidence of Listeria spp. in raw milk and dairy products.

\begin{tabular}{|c|c|c|c|c|}
\hline $\begin{array}{c}\text { Examined } \\
\text { samples }\end{array}$ & $\begin{array}{c}\text { No. of } \\
\text { examined } \\
\text { samples }\end{array}$ & $\begin{array}{c}\text { No. of } \\
\text { positive } \\
\text { samples }\end{array}$ & $\%$ \\
\hline \multirow{3}{*}{ Raw milk } & Cow's milk & 50 & 3 & 6.0 \\
\cline { 2 - 5 } & Sheep's milk & 25 & 0 & 0.0 \\
\cline { 2 - 5 } Dairy products & Goat's milk & 25 & 2 & 8.0 \\
\hline & Pasteurized milk & 25 & 0 & 0.0 \\
\cline { 2 - 5 } & $\begin{array}{c}\text { White soft } \\
\text { cheese }\end{array}$ & 25 & 1 & 4.0 \\
\cline { 2 - 5 } & Plain yoghurt & 25 & 0 & 0.0 \\
\cline { 2 - 5 } & Fruit yoghurt & 25 & 0 & 0.0 \\
\hline Total & & 200 & 6 & 3.0 \\
\hline
\end{tabular}

Table 2: Incidence of different types of Listeria spp. microorganisms in raw milk and dairy products.

\begin{tabular}{|c|c|c|c|c|c|}
\hline \multirow{2}{*}{$\begin{array}{c}\text { Examined } \\
\text { samples }\end{array}$} & \multirow[t]{2}{*}{ Products } & \multirow{2}{*}{$\begin{array}{c}\text { No. } \\
\text { of samples }\end{array}$} & \multicolumn{3}{|c|}{ No. of samples positive for } \\
\hline & & & $\begin{array}{c}L . \\
\text { monocytogens }\end{array}$ & $\begin{array}{c}\text { L. } \\
\text { innocua } \\
\end{array}$ & $\begin{array}{c}L . \\
\text { welshimeri }\end{array}$ \\
\hline \multirow{3}{*}{ Raw milk } & Cow's milk & 50 & 1 & 3 & 1 \\
\hline & Sheep's milk & 25 & 0 & 0 & 0 \\
\hline & Goat's milk & 25 & 1 & 2 & 0 \\
\hline \multirow{4}{*}{$\begin{array}{c}\text { Dairy } \\
\text { products }\end{array}$} & $\begin{array}{l}\text { Pasteurized } \\
\text { milk }\end{array}$ & 25 & 0 & 0 & 0 \\
\hline & $\begin{array}{l}\text { White soft } \\
\text { cheese }\end{array}$ & 25 & 1 & 0 & 1 \\
\hline & Fruit yoghurt & 25 & 0 & 0 & 0 \\
\hline & Plain yoghurt & 25 & 0 & 0 & 0 \\
\hline Total & & 200 & $3(1.5 \%)$ & $\begin{array}{c}5 \\
(2.5 \%)\end{array}$ & $2(1.0 \%)$ \\
\hline
\end{tabular}

Table 3: Incidence of Yersinia spp. in raw milk and dairy products. 
Assiut Vet. Med. J. Vol. 55 No. 123 October 2009

\begin{tabular}{|c|c|c|c|c|}
\hline Examined samples & Products & $\begin{array}{c}\text { No. of } \\
\text { examined } \\
\text { samples }\end{array}$ & $\begin{array}{c}\text { No. of } \\
\text { positive } \\
\text { samples }\end{array}$ & $\%$ \\
\hline \multirow{3}{*}{ Raw milk } & Cow's milk & 50 & 20 & 40.0 \\
\cline { 2 - 5 } & Sheep's milk & 25 & 5 & 20.0 \\
\cline { 2 - 5 } & Goat's milk & 25 & 8 & 32.0 \\
\hline \multirow{4}{*}{ Dairy products } & Pasteurized milk & 25 & 1 & 4.0 \\
\cline { 2 - 5 } & $\begin{array}{c}\text { White soft } \\
\text { cheese }\end{array}$ & 25 & 2 & 8.0 \\
\cline { 2 - 5 } & Plain yoghurt & 25 & 3 & 12.0 \\
\cline { 2 - 5 } & Fruit yoghurt & 25 & 2 & 8.0 \\
\hline Total & & 200 & 41 & 20.5 \\
\hline
\end{tabular}

Table 4: Incidence of different types of Yersinia spp. microorganisms in raw milk and dairy products

\begin{tabular}{|c|c|c|c|c|c|c|c|}
\hline \multirow{2}{*}{$\begin{array}{c}\text { Examined } \\
\text { samples }\end{array}$} & Products & \multirow{2}{*}{$\begin{array}{c}\text { No. } \\
\text { of samples }\end{array}$} & \multicolumn{6}{|c|}{ No. Of samples positive for } \\
\cline { 3 - 8 } & & $\begin{array}{c}\text { Y. entero- } \\
\text { colitica }\end{array}$ & $\begin{array}{c}\text { Y. inter- } \\
\text { media }\end{array}$ & $\begin{array}{c}\text { Y. kristen- } \\
\text { senii }\end{array}$ & $\begin{array}{c}\text { Y. fredrik- } \\
\text { senii }\end{array}$ & $\begin{array}{c}\text { Y. psudo- } \\
\text { tuberculosis }\end{array}$ \\
\hline \multirow{2}{*}{$\begin{array}{c}\text { Raw } \\
\text { milk }\end{array}$} & Cow's milk & 50 & 5 & 10 & 3 & 0 & 4 \\
\cline { 2 - 8 } & $\begin{array}{c}\text { Sheep's } \\
\text { milk }\end{array}$ & 25 & 1 & 2 & 0 & 3 & 0 \\
\cline { 2 - 8 } & Goat's milk & 25 & 2 & 0 & 0 & 4 & 4 \\
\hline \multirow{2}{*}{$\begin{array}{c}\text { Dairy } \\
\text { products }\end{array}$} & $\begin{array}{c}\text { Pasteurized } \\
\text { milk }\end{array}$ & 25 & 0 & 1 & 0 & 0 & 0 \\
\cline { 2 - 8 } & $\begin{array}{c}\text { White soft } \\
\text { cheese }\end{array}$ & 25 & 1 & 2 & 0 & 0 & 0 \\
\cline { 2 - 8 } & $\begin{array}{c}\text { Fruit } \\
\text { yoghurt }\end{array}$ & 25 & 1 & 0 & 1 & 0 & 2 \\
\cline { 2 - 8 } & $\begin{array}{c}\text { Plain } \\
\text { yoghurt }\end{array}$ & 25 & 1 & 0 & 1 & 1 & 0 \\
\hline Total & & 200 & $11(5.5 \%)$ & $15(7.5 \%)$ & $5(2.5 \%)$ & $8(4.0 \%)$ & $10(5.0 \%)$ \\
\hline
\end{tabular}

\section{DISCUSSION}

Data presented in Table 1 indicate an overall Listeria spp. incidence of $3.0 \%$ in raw milk and dairy product samples. Proportions of $6.0 \%$ in cow's milk, $8.0 \%$ in goat's milk and $4.0 \%$ in white soft cheese samples were positive for presence of Listeria spp. This corresponding to an incidence level that previously reported by Breer and Schopfer (1989) and Yoshida et al. (1998). While higher levels of contamination were detected by Farber et al. (1988); Hassan et al. (2000) and Aysel et al. (2006). It is interesting to note that Listeria spp. can't be detected in sheep's milk, pasteurized milk and both fruit and plain yoghurt samples 
indicating that the hygienic standards were extremely applied during the production stages.

Table 2 showed that among cow's milk samples positive for Listeria monocytogens one of three contained, in addition to this organism another species of Listeria: Three samples had L. innocua and one has L. welshimeri. Nearly similar finding of L. monocytogens in milk was reported by Farber et al. (1988). Higher prevalence of L. monocytogens was reported by El-Sherbini (1990) and Jayarao and Henning (2001). Terplan et al. (1986) and Stone (1987) failed to detect L. monocytogens in cow's milk. Two goat's milk samples contained L. innocua and L. monocytogens. Løken et al. (1982) recovered L. monocytogens from goat's milk (11.4\%). Only one sample of white soft cheese has L. monocytogens and L. welshimeri. Higher percentages of L. monocytogens in white soft cheese were reported by Pini and Gilbert (1988) 10.0\%; Breer and Schopfer (1989) 3.0\%; El-Sherbini (1990) 16.0\% and Aysel et al. (2006) 4.0\%.

Previously mentioned findings revealed that among the examined dairy products, only white soft cheese was contaminated by Listeria monocytogens and this result is in agreement with that reported by Pini and Gilbert (1988) and Breer and Schopfer (1989). As an explanation to that, contamination may occurred during the ripening process due to the higher $\mathrm{pH}$ of cheese at the later stages of ripening which should be considered a hygienic problem.

The results recorded in Table 3 decleared that Yersinia spp. could be isolated from $41(20.5 \%)$ of the examined raw milk and dairy product samples. The incidence percentages were variable as follow: $40.0 \%$ in cow's milk, $20.0 \%$ in sheep's milk, $32.0 \%$ in goat's milk, $4.0 \%$ in pasteurized milk, $8.0 \%$ in white soft cheese, $12.0 \%$ in fruit yoghurt and $8.0 \%$ in plain yoghurt samples. These findings of raw milk are in agreement with that reported by Franzin et al. (1984); Umoh et al. (1984); Ibrahim and MacRae (1991) and Awad (2002 ). While higher results obtained by Vidon and Delmas (1981); Walker and Gilmour (1986); MacManus and Lanier (1987); Adriana et al. (1994) and Ozbaz (2000). Lower results were recorded by Fukushima et al. (1986); Syed et al. (1989); Hamama et al. (1992); Mohamed et al. (2004) and Jayarao et al. (2006). While Quaglio et al. (1988), Desmasures et al. (1997) and Ramesh et al. (2002) could not isolate Yersinia from raw milk sample. Results of pasteurized milk are lower than that mentioned by Hamama et al. (1992) and Adriana et al. (1994). While Syed et al. (1989) and Mohamed et al. (2004) failed to detect Yersinia in pasteurized milk. 
Hamama et al. (1992) reported nearly similar findings of white soft cheese and higher values with yoghurt samples.

The presence of Yersinia spp. in pasteurized samples can be explained either by post- pasteurization contamination or by the presence of a heat resistant strain. Insufficiently cleaned milk equipment was the most frequently incriminated source of pasteurized milk contamination with Yersinia spp. While, in fermented milk its presence can be explained by the use of initially contaminated milk for their preparation or due to fermented milk are consumed within $36 \mathrm{hrs}$. period following their manufacture, this period of time might not be sufficient to destroy all Yersinia present in these acidic products as Yersinia was found to survive for one week in yoghurt $\mathrm{pH}$ (4.5). Yersinia spp. in fresh cheese could be attributed to different factors such as the use of raw milk and the eventual contamination from human handlers, environment and water Hamama et al. (1992).

The results tabulated in Table 4 revealed that Yersinia enterocolitica, Yersinia intermedia, Yersinia kristensenii, Yersinia frederiksenii and Yersinia pseudotuberculosis could be detected in $(5,1,2,0,1,1$ and 1\%); (10, 2, 0, 1, 2, 0 and $0 \%) ;(3,0,0,0,0,1$ and $1 \%) ;(0,3,4,0,0,0$ and $1 \%)$ and $(4,0,4,0,0,2$ and $0 \%)$ of the examined cow's milk, sheep's milk, goat's milk, pasteurized milk, white soft cheese, fruit yoghurt and plain yoghurt samples, respectively. Hamama et al. (1992) could identify the same isolates from cow's milk, white soft cheese and yoghurt. While, Syed et al. (1989); Fukushima et al. (1986); Catton and White (1992) and Jayarao and Henning (2001) could isolate only Yersinia enterocolitica.

High incidence of Yersinia enterocolitica in milk and its products was significantly related to high bacterial counts (Catton and White, 1992) and implies that these products are a likely sources of contamination with Yersinia (Adriana et al., 1994). An increase in Yersinia enterocolitica number was observed during manufacture, although its number was decreased following salting and through out the storage period of cheese (Osman, 1996). Water is believed to be an important source of Yersinia enterocolitica as several studies indicate that Yersinia enterocolitica outbreaks in human are mainly caused by consumption of contaminated food and water. Raw milk and inadequately pasteurized milk and milk products have also been implicated in transmission of $Y$. enterocolitica infections to humans (Black et al., 1978). Epidemiological studies in food microbiology revealed that refrigerated food stored over a long period pose an 
additional risk, because Yersinia, as a psychrotrophic microbe, is able to grow at temperatures as low as $0{ }^{\circ} \mathrm{C}$ (Hanna et al., 1976). These microorganisms have been isolated in different countries from raw milk: in Australia (Ibrahim and Mac Rae, 1991; Hughes, 1979), Canada (Schiemann, 1978), France (Vidon and Delmas, 1981), Ireland (Walker and Gilmour, 1986), Italy (Franzin et al., 1984) and USA (Moustafa et al., 1983). Although there are over 50 different serotypes of Yesinia enterocolitica, serogroups, 0:3, 0:5, 27, 0:8 and 0:9 are generally regarded as the most common human pathogens (Toora, 1995). Yersinia enterocolitica produce a heat-stable enterotoxin (ST), which shows serological cross- reactivity to E.coli ST. Usually it can not be produced above $30^{\circ} \mathrm{C}$, can not be found in vivo and is common in non pathogenic environmental strains mainly $\mathrm{O}: 3$ can cause enteritis to children aged 1-4 years which is characterized by heavy watery and sometimes bloody diarrhea, abdominal cramps, fever and vomiting, symptoms which lasts normally only for 1-2 days while in people between 10-14 years old. It leads to pseudoappendicitis which seems to be typical for Yersiniosis. Arthritis of extremities is the most usual complication of Yersiniosis in young people while erythma nodosum as sequellae is known specially for women older than 40 years. Septicemia is rare due to invasion of Yersinia enterocolitica in the circulatory system, but result in a lethality rate of $30 \%$.

Yersinia kristensenii are usually environmental strains and are not generally associated with human gastrointestinal infections but can act as opportunistic pathogens and cause extra intestinal infections (Bercovier and Mollaret, 1984).

From our conducted study we concluded that contamination of milk and dairy products by these pathogenic microorganisms can be of endogenous origin, following excretion from the udder of an infected animals or may be also of exogenous origin, through direct contact with infected herd or through environment (water and personnel). Attention toward the way by which the restriction of these microorganisms must be done because it is the primary concerns for safety assurance in the dairy industry. This can be achieved by hygiene in all aspects of milk handling (Farm hygienic measures), strict maintenance of refrigeration $4^{\circ} \mathrm{C}$ or lower, minimization of the storage time of raw milk, deficiencies in the hygienic measures of milk and dairy products storage particularly refrigeration that was not properly implemented should be corrected and a suitable method to kill or remove these microorganisms, where heat treatment and processing of milk can inhibit or encourage the 
multiplication of these microorganisms followed up by an effective HACCP system.

\section{REFERENCES}

A.P.H.A. (1992): Standard methods for the examination of dairy products. $16^{\text {th }}$ Ed., Amer. Pub. Health Assoc., New York.

Adriana, D.R.T.; Bernadette, D.G.F. and Mariza, L. (1994): Incidence of Yersinia spp. in food in Sao Paulo, Brazil. Int. J. of Food Microbiol., 21: 263-270.

Aulisio, C.C.G. and Stanfield, J.T. (1984): Yersinia enterocolitica and Yersinia pseudotuberculosis. In: US Food and Drug Administration. Division of Microbiology. Bacteriological Analytical Manual. $6^{\text {th }}$ Ed., Washington, DC, AOAC.

Awad, I.E. (2002): Studies on food poisoning bacteria with special reference to Campylobacter jejuni in milk. Ph.D Thesis, Fac. of Vet. Med., Zagazig Univ., Egypt.

Aygun, P. and Pehlivanlar, S. (2006): Listeria spp. in the raw milk and dairy products in Antakya, Turkey. Food Control; 17: 599-682.

Aysel, B.Ö.; Göktug, B.; Ahmet, E.C. and Gülderen, Y. (2006): Prevalence of L. monocytogens in some Turkish food stuffs. J. of Food Quality. 29: 76-86.

Bercovier, H.; Brenner, D.J.; Ursing, J.; Steigerwalt, A.G.; Fanning, G.R.; Alonso, J.M.; Carter, G.P. and Mollaret, H.H. (1980): Characterization of Yersinia enterocolitica sensu stricto. Curr. Microbiol., 4: 201-206.

Bercovier, H. and Mollaret, H.H. (1984): Yersinia In: Krieg. N. R. (ed), Bergey's_Williams and Wilkins, Baltimore, pp. 489-506.

Bille, J.; Catimel, B.; Bannerman, E.; Jacquet, C.; Yersin, M. N.; Caniaux, I.; Monget, D. and Rocourt, J. (1992): API-Listeria, a new and promising one-day system to identify listeria isolates. Appl. and Environ. Microbiol., 58 (6): 1857-1860.

Black, R.E.; Jackson, R.J.; Tsai, T.; Medvesky, M.; Shayegani, M.; Feeley, J.C.; MacLeod, K.I.E. and Wakelee, A.M. (1978): Epidemic Yersinia enterocolitica infection due to contaminated chocolate milk. N. Engl. J. Med., 298: 76-79.

Bottone, E.J. (1997): Yersinia enterocolitica: the carisma continues. Clin. Microbiol. Reviews, 10: 257-276.

Breer, C. and Schopfer, K. (1989): Listeria in food. Schweiz Med. Wochenschr. 11; 119 (10): 306-11. 
Cotton, L.N. and White, C.H. (1992): Listeria monocytogenes, Yersinia enterocolitica and Salmonella in dairy plant environments. J. Dairy Sci. 75: 51-57.

Desmasures, N.; Bazin, F. and Gueguen, M. (1997): Microbiological composition of raw milk from selected farms in the Camembert region of Normandy, J. Appl. Microbiol., 83 (6): 53-58.

El-Sherbini, M.A.A. (1990): Occurrence and behaviour of pathogenic microorganisms especially Listeria monocytogenes in milk and some dairy products. Ph.D Thesis, Fac. of Vet. Med., Zagazig Univ., Egypt.

Farber, J.M.; Sanders, G.W. and Malcolm, S.A. (1988): The presence of Listeria spp. in raw milk in Ontario. 34 (2): 95-100.

Fleming, D.W.; Cochi, S.L.; MacDonald, K.L.; Brondum, J.; Hayes, P.S.; Plikaytis, B.D.; Holmes, M.B.; Audurier, A.; Broome, C.V. and Reingold, A.L. (1985): Pasteurized milk as vehicle of infection in outbreak of Listeriosis. New Engl. J. Med., 312: 404-407.

Franz, A. (2003): Listeria: growth, phenotypic differentiation and molecular microbiology. FEMS Immunol. and Med. Microbiol., 35: 183-189.

Franzin, L.; Fantino, P. and Vidotto, V. (1984): Isolation of Yersinia enterocolitica and Yersinia enterocolitica-like organisms from raw milk in Italy. Current Microbiol., 10(1984): 357-360.

Fukushima, H.; Tsubokura, M.; Otsuki, K. and Kawaoka, Y. (1986): Suppression of Heat-stable Enterotoxin production by Y. spp. in milk. Veterinary Microbiol., 11: 163-172.

Hamama, A.; El Marrakchi, A. and El Othmani, F. (1992): Occurrence of Yersinia enterocolitica in milk and dairy products in Morocco. Int. J. of Food Microbiol., 16: 69-77.

Hanna, M.O.; Zink, Z.L. and Vanderzant, C. (1976): Yersinia enterocolitica-like organisms from vacuum-packaged beef and lamb. J. Food Sci., 41: 1254-1256.

Hassan, L.; Mohammed, H. O.; McDonough, P. L.; Gonzalez, R. A. (2000): A cross-sectional study on the prevalence of Listeria monocytogenes and Salmonella in New York dairy herds. J. Dairy Sci. 83 (11): 2441-7.

Herman, L.; De Block, J. and Moermans, R. (1995): Direct detection of Listeria monocytogenes in 25 milliliters of raw milk by a two- 
step PCR with nested primers. Appl. Environ. Microbiol., 61: 817-9.

Hughes, D. (1979): Isolation of Yersinia enterocolitica from milk and a dairy farm in Australia. J. Appl. Bacteriol., 46: 125-130.

Ibrahim, A. and Mac Rae, I.C. (1991): Isolation of Yersinia enterocolitica and related from red meat and milk., J. Food Sci., 56 (6): 1524-1526.

Jansen, B.; Kohnen, W.; Obst, U. and Schwartz, T. (2003): Detection of antibiotic-resistant bacteria and their resistance genes in wastewater, surface water, and drinking water biofilms. FEMS. Microbiol. Ecol., 43: 325-35.

Jayarao, B.M. and Henning, D.R. (2001): Prevalence of foodborne pathogens in Bulk Tank Milk. J. Dairy Sci., 84 (10): 2157-62.

Jayarao, B.M. ; Donaldson, S. C.; Straley, B. A.; Sawant, A. A.; Hegde, N. V.; Kells, J. and Gilmour, A. (2004): Incidence of Listeria monocytogenes in two milk processing environments and assessment of Listeria monocytogenes blood agar for isolation. Int. J. Food Microbiol., 91: 167-74.

Landgraf, M. (1993): An improved enrichment procedure for isolation of Yersinia enterocolitica and related species from milk. J. of Food Prot., 56: 447-450.

Larkin, L.L.; Vasavada, P.C. and Marth, E.H. (1991): Incidence of Yersinia enterocolitica in raw milk as related to its quality. Milchwissenschaft, 46: 500-502.

LoØken, T.; AspØy, E. and GrØnstØl, H. (1982): Listeria monocytogenes execution and humoral immunity in goats in a herd without breaks of listeriosis and in a healthy herd. Acta Vet. Scand. 23: 392-399.

Lovett, J. (1989): Listeria monocytogenes. In M.P. Doyle (Ed.), Foodborne Bacterial Pathogens (pp. 283-310). New York: Marcel Dekker.

Makino, S.I.; Kawamoto, K.; Takeshi, K.; Okada, Y.; Yamasaki, M. and Yamamoto, S. (2005): An outbreak of food-borne Listeriosis due to cheese in Japan, during 2001. Int. J. Food Microbiol., 104: 189-96.

Manfreda, G.; De Cesare, A.; Stella, S.; Cozzi, M. and Cantoni, C. (2005): Occurrence and ribotypes of Listeria monocytogenes in Gorgonzolla cheese. Int. J. Food Microbiol., 102: 287-93.

McLauchlin, J. (1997 a): The discovery of Listeria. PHLS Microbiol. Digest., 14: 76-78. 
McLauchlin, J. (1997 b): The pathogenicity of Listeria monocytogenes: A public health perspective. Reviews in Medical Microbiology, 8: $1-14$.

McLauchlin, J.; Mitchell, R.; Smerdon, W. and Jewell, K. (2004): Listeria monocytogenes and Listeriosis: a review of hazard characterization for use in microbiological risk assessment of foods. Int. J. Food Microbiol., 92: 15-33.

McManus, C. and Lanier, J.M. (1987): Salmonella, Campylobacter jejuni and Yersinia enterocolitica in raw milk. J. Food Prot., 50(1): 51-55.

Meyer-Broseta, S.; Diot, A.; Bastian, S. and Riviere, Cerf. O. (2003): Estimation of low bacterial concentration: Listeria monocytogenes in raw milk. Int. J. Food Microbiol., 80: 1-15.

Mohamed, M.S.D.; Alijan, T. and Koorosh, M. (2004): Comparison of four methods for isolation of Yersinia enterocolitica from raw and pasteurized milk from Northen Iran. Int. J. of Food Microbiol., 94: 87-91.

Moustafa, M.K.; Ahmed, A.A-H. and Marth, E.H. (1983): Occurrence of Yersinia enterocolitica in raw and pasteurized milk. J. Food Prot., 46: 276-278.

Neubauer, H.; Sauer, T.; Becker, H.; Aleksic, S. and Meyer, H. (1998): Comparison of systems for identification and differentiation of species within genus Yersinia. J. Clin. Microbiol., 36: 3366-3368.

Osman, E. (1996): Survival of virulent Y. enterocolitica during the manufacture and storage of Turkish Feta cheese. Int. J. of Food Microbiol., 33: 285-292.

Oxoid (1990): The Oxoid Manual. $6^{\text {th }}$ edition, Unipath. Ltd. U.K.

Ozbas, Z.Y.; Lehner, A. and Wagner, M. (2000): Development of multiplex and semi-nested PCR assay for detection of Yersinia enterocolitica and Aeromonas hydrophila in raw milk., Food Microbiol., 17: 197-203.

Pini, P.N. and Gilbert, R.J. (1988): The occurrence in the U. K. of Listeria species in raw chickens and soft cheeses. Int. J. of Food Microbiol., 6 (4): 317-26.

Quaglio, P.; Aggazzotti, G.; Montovani, G.; Messi, P. and Fabio, A. (1988): A study on the presence of Yersinia spp. in milk and bovine feaces., L'Igiene Moderna, 90: 585-596.

Ramesh, A.; Padmapriya, B.P.; Chrashekar, A. and Varadaraj, M.C. (2002): Application of convenient DNA extraction method and 
Multiplex PCR for the direct detection of Staphylococcus aureus and Yersinia enterocolitica in milk samples., Mol. Cell. Probes., 16 (4): 307-314.

Robins-Browne, R.M. (1997): Yersinia enterocolitica. In: Doyle, M. P.; Beuchat, L.R. and Montville, T.J. (eds), Food Microbiol.: Fundamentals and Frontiers, pp. 192-215. ASM press, Washington.

Schiemann, D. A. (1978): Association of Yersinia enterocolitica with the manufacture of cheese and occurrence in pasteurised milk. Appl. Environ. Microbiol., 36: 274-277.

Siegman-Igra, Y.; Levin, R.; Weinberger, M.; Golan, Y.; Schwartz, D. and Samra, Z. (2002): Listeria monocytogenes infection in Israel and review of cases worldwide. Emerg. Infect. Dis.; 8: 305-10.

Stone, D.L. (1987): A survey of raw whole milk for C. jejuni, L. monocytogens and Y. enterocolitica. N. Z. Dairy Sci. Technol., 22: $257-264$.

Swaminathan, B. (2001): Listeria monocytogenes. In M. P. Doyle, L.R. Beuchat, \& T.J. Montville (Eds.), Food Microbiology Fundamentals and Frontiers (pp. 383-410). Washington: ASM Press.

Syed, T.; Gagandeep, S.; Ram, P.T. and Gurinder, S. (1989): Drug resistance and Lecithinase activity of Y. enterocolitica isolated from buffalo milk. Int. J. Food Microbiol., 9: 167-171.

Terplan, G.; Schoen, R.; Springmeyer, W.; Degle, I. and Becker, H. (1986): L. monocytogens in Milch und Milch produkten. Archiv fur Lebensmittel hygiene, 37, 129-156.

Teuber, M. (1999): Spread of antibiotic resistance with food-borne pathogens. CMSL Cell Mol. Life Sci., 56: 755-61.

Toora, S. (1995): Inactivation of pathogenic serotypes of Yersinia enterocolitica by chlorine., J. Food Prot., 58 (12): 1383-1385.

Umoh, V.J.; Dangana, A. and Umoh, J.U. (1984): Isolation of Yersinia enterocolitica from milk and milk products in Zaria, Nigeria. Int. J. Zoon., 11: 223-228.

Van-Netten, P.; Perales, I.; Van-De-Moosdijik, A.; Curtis, G.D.W. and Mossel, D.A.A. (1989): Liquid and solid selective differential media for the detection and enumeration of Listeria monocytogenes and other Listeria spp. Int. J. of Food Microbiol., 8: 299-316. 
Vela, A.; Fernandez-GarayzáBal, J.; Latre, M.; Rodriguez, A.; Dominguez, L. and Moreno, M. (2001): Antimicrobial susceptibility of Listeria monocytogenes isolated from meningoencephalitis in sheep. Int. J. Antimicrob Agents; 17: 215-20.

Vidon, J.M. and Delmas, C.L. (1981): Incidence of Yersinia enterocolitica in raw milk in eastern France., Appl. and Environ. Microbiol., 41 (2): 355-359.

Walker, S.J. and Gilmour, A. (1986): The incidence of Yersinia enterocolitica and Yersinia enterocolitica- like organisms in raw and pasteurized milk in Northern Ireland. J. Appl. Bacteriol., 61 (2): 133-138.

Yoshida, T.; Sato, M. and Hirai, K. (1998): Prevalence of Listeria species in raw milk from farm bulk tanks in Nagano prefecture. J. of Vet. Med. Sci., 60 (3): 311-314. 